\title{
EVALUATION OF SCINTILLATION PROBE PROFILES FROM 200 AREA CRIB MONITORING WELLS \\ VOLUME I
}

K. R. Fecht

G. V. Last

K. R. Price

Research Department

Research and Engineering Division

\author{
June 1977
}

Atlantic Richfield Hanford Company

Richland, Washington 99352 


\section{DISCLAIMER}

This report was prepared as an account of work sponsored by an agency of the United States Government. Neither the United States Government nor any agency Thereof, nor any of their employees, makes any warranty, express or implied, or assumes any legal liability or responsibility for the accuracy, completeness, or usefulness of any information, apparatus, product, or process disclosed, or represents that its use would not infringe privately owned rights. Reference herein to any specific commercial product, process, or service by trade name, trademark, manufacturer, or otherwise does not necessarily constitute or imply its endorsement, recommendation, or favoring by the United States Government or any agency thereof. The views and opinions of authors expressed herein do not necessarily state or reflect those of the United States Government or any agency thereof. 


\section{DISCLAIMER}

Portions of this document may be illegible in electronic image products. Images are produced from the best available original document. 


\section{TABLE OF CONTENTS}

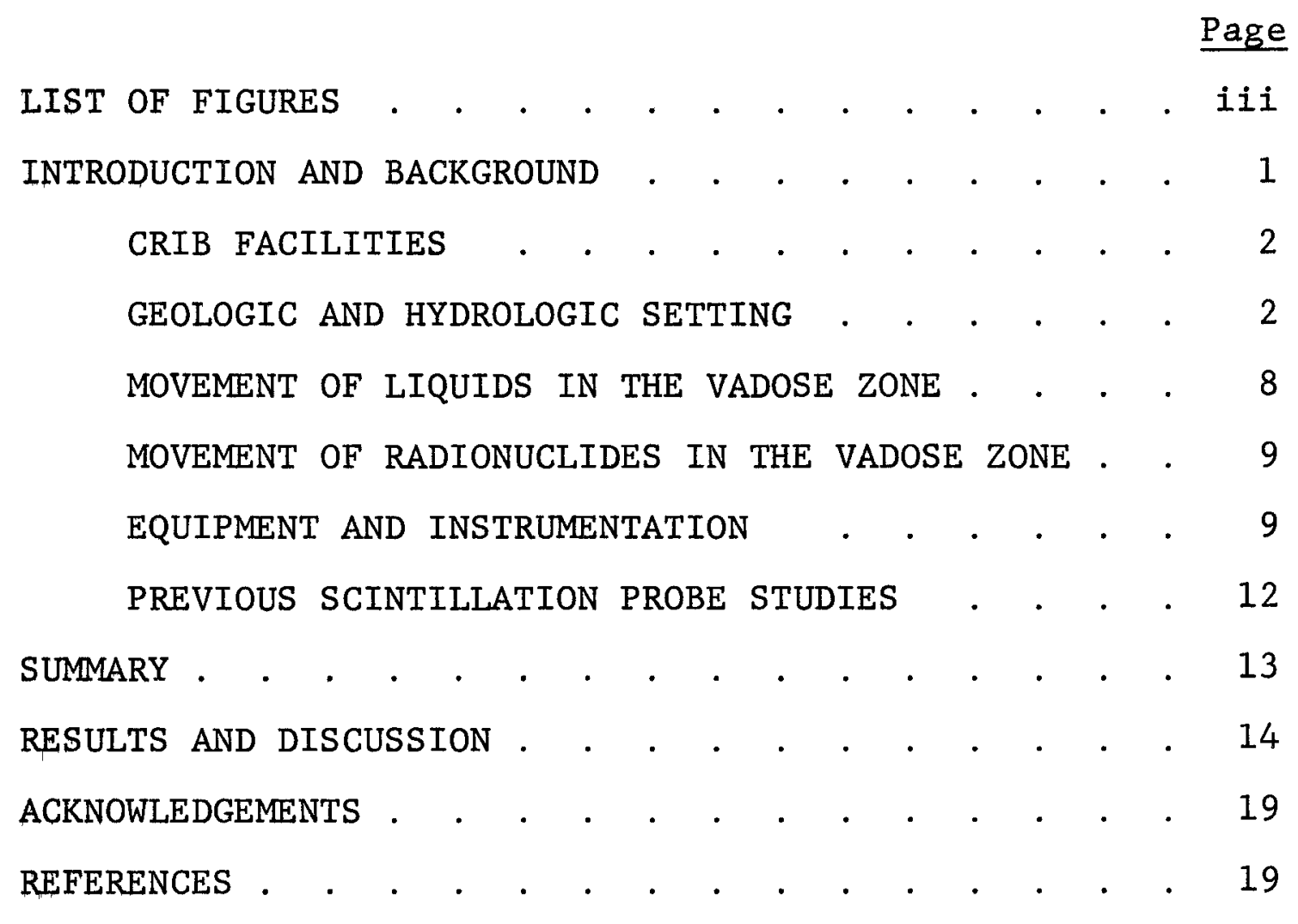




\section{LIST OF FIGURES}

Page

FIGURE 1

GEOGRAPHY OF HANFORD RESERVATION

FIGURE 2

$$
\begin{aligned}
& \text { STRATIGRAPHIC CHART OF THE PASCO } \\
& \text { BASIN }
\end{aligned}
$$

FIGURE 3

GEOLOGIC CROSS-SECTIONS OF 200 AREAS

FIGURE 4 


\section{EVALUATION OF SCINTILLATION PROBE PROFILES FROM 200 AREA CRIB MONITORING WELLS}

\section{INTRODUCTION AND BACKGROUND}

Ground disposal of liquid radioactive waste from Hanford separations plants began on a limited basis in 1945. [1] Smal1 volumes of selected radioactive waste were initially discharged to the ground by means of subsurface structures or crib facilities. As more was learned about site geology and wastesediment interactions, it was concluded that increased volumes of liquid effluent and increased quantities of radionuclides could be safely disposed of in the ground if properly controlled. Waste discharged to the ground was then greatly increased, reaching a peak of $8.34 \times 10^{5}$ curies discharged in 1955. [2] Thereafter, the volume and quantity of radioactive waste discharge were decreased as ground disposal of radionuclides was minimized and separation plants were shut down.

The purpose of this study, as with two earlier studies conducted in 1964 and 1969, is to measure qualitatively the distribution, redistribution and decay of radionuclides beneath crib facilities. ${ }^{[3,4]}$ For this study, nearly 300 crib monitoring wells adjacent to approximately $100 \mathrm{crib}$ facilities were logged with a scintillator, a devise for measuring radioactivity. The profiles for each well were compared with selected profiles developed between 1954 and 1973. Volume II (Appendix A) and Volume III (Appendix B) contain selected scintillation probe profiles from crib monitoring wells, background information for cribs (waste description, waste inventory and service dates) and an evaluation of radionuclides in the ground, which 
are listed by crib facility for 200 East Area and 200 West Area, respectively. The distribution, redistribution and decay of radionuclides in the vadose zone are discussed in Volume I.

\section{CRIB FACILITIES}

Liquid wastes that contain intermediate levels of radioactive contaminants are discharged to the ground by means of underground structures collectively termed crib facilities. There have been 195 crib facilities constructed for disposal of waste to the ground in the 200 Areas. Several types of crib facilities have been utilized at Hanford: (1) cribs, which are liquid dispersion systems, used for the disposal of process, condensate and lab wastes; (2) trenches, which are unlined excavations, generally used for short periods for the disposal of high-salt waste or waste containing complexed radionuclides on a specific retention basis; (3) french drains, which are covered or buried gravel-filled encasements with open bottoms, used for the disposal of small-volume and generally low-level waste; and (4) reverse wells, which are buried or covered encased drilled holes with the lower end perforated or open, used for the disposal of process waste. [5] Reverse wells proved unsatisfactory because they plugged easily and introduced waste to the ground at or near the groundwater. [6] Therefore, by 1954, all reverse wells had been removed from service and waste was routed to other types of cribs.

GEOLOGIC AND HYDROLOGIC SETTING

The Hanford Reservation of almost 1500 square kilometers lies in a broad structural and topographic basin, the Pasco Basin, which is located in south-central Washington. The 
study areas located in 200 East Area and 200 West Area lie in the center of the Hanford Reservation (Figure 1).

The 200 Areas are underlain by three major stratigraphic units (Figure 2). They are in ascending order: (1) Yakima Basalt of the Columbia River Basalt Group which forms the bedrock beneath the Reservation; (2) semiconsolidated sediments of the Ringold Formation which directly overlie the bedrock; and (3) unconsolidated sands, silts and gravels, collectively termed glaciofluvial deposits. [7]

Yakima Basalt

Between 20 and 40 million years ago, a series of fissures opened around the periphery of the Pasco Basin and intermittently extruded large volumes of basaltic lava. At the cessation of the volcanism approximately eight million years ago, more than 3,200 meters of basalt had accumulated in the subsiding Pasco Basin.

Ringold Formation

Following the cessation of the Columbia River Basalt volcanism during the Pliocene-Pleistocene epochs, sediments from the surrounding highlands were transported by the ancestral Columbia River into the subsiding Pasco Basin where they accumulated to form the Ringold Formation. Beneath the 200 Areas, this formation is up to 122 meters thick and consists primarily of well rounded pebbles and cobbles with the interstitial spaces filled with medium to fine sand. In places, these sediments are cemented with silica or calcium carbonate.

After deposition of the Ringold Formation, the top of the unit was subjected to subaerial erosion during an arid 


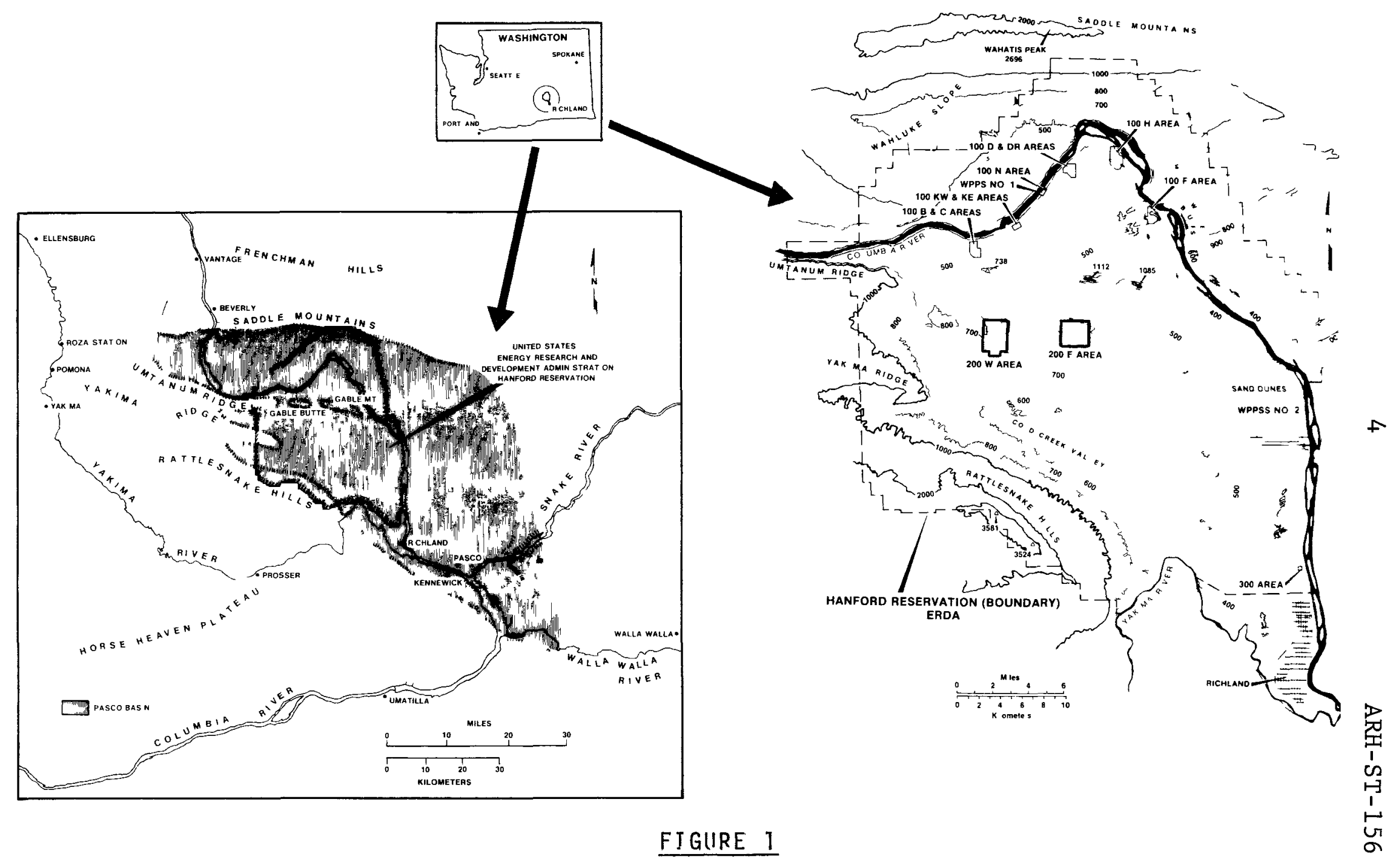

GEOGRAPHY OF HANFORD RESERVATION 
STRATIGRAPHY OF THE PASCO BASIN

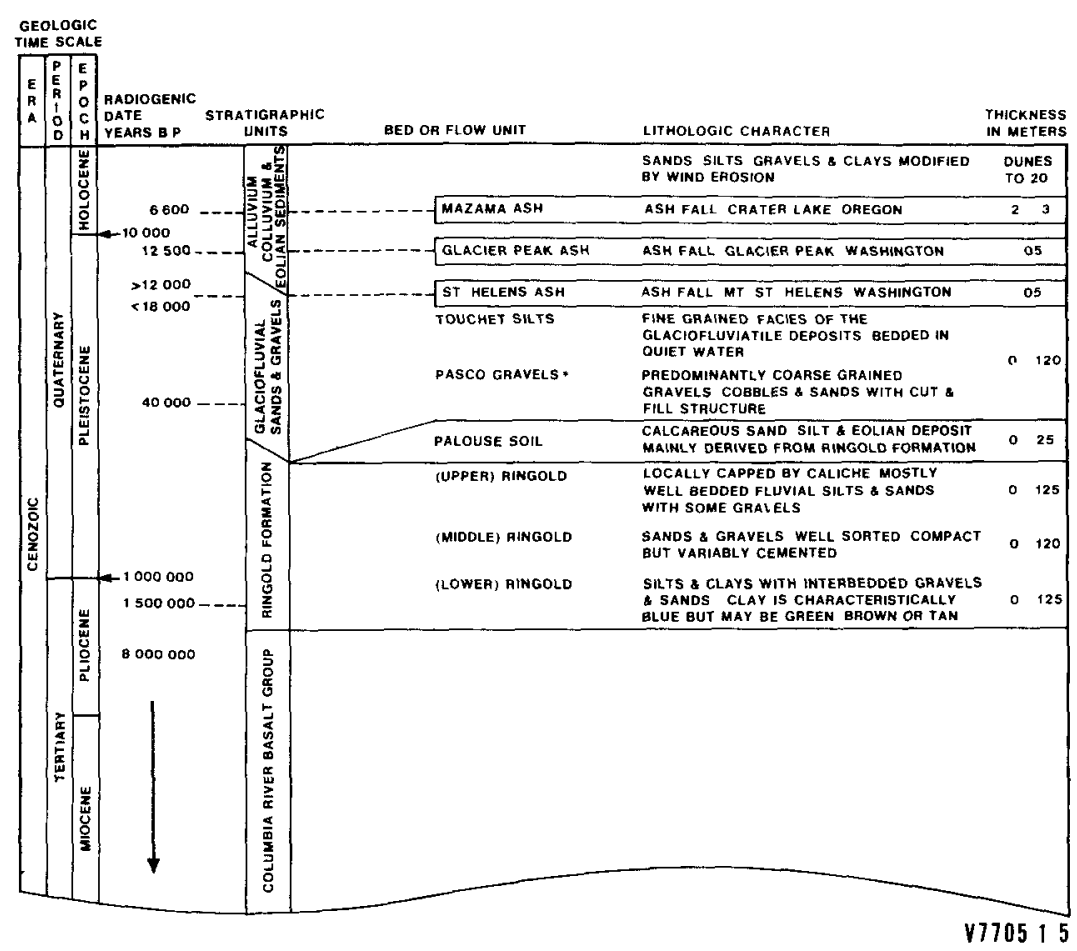

FIGURE 2 
period comparible to that of today. The surface of the Ringold Formation was altered by wind which winnowed, reworked and redeposited the fine-grained sands and silts. An eolian silt, up to 30 meters thick, is found underlying 200 West Area and the western part of the Reservation. Elsewhere, the unit has been eroded by the glacial meltwater. These wind deposited sediments are termed Early Palouse soils (loesses) or eolian silt. With the dry climate, layers of caliche formed in the eolian silt and in the top of the Ringold Formation.

\section{Glaciofluvial Deposits}

During the close of the Ice Age, 10,000 to 20,000 years ago, breakup of ice dams resulted in catastrophic floods in which large volumes of glacial meltwaters were released, periodically flooding the Pasco Basin. In places, the floods scoured the then-existing land surface, the eolian silt and upper Ringold units, deeply eroding the Ringold Formation. The glacial meltwaters were hydraulically dammed at Wallula Gap, and water was impounded in the Pasco Basin to an elevation of 335 meters above sea level. The velocity of the flood waters diminished and up to 82 meters of unconsolidated sediments were deposited beneath the 200 Areas. The major stratigraphic units found within the glaciofluvial deposits are shown in Figure 3.

The water table lies 56 to 107 meters beneath the surface of the separations areas in the upper portion of the Ringold Formation. Above the water table, the unconsolidated sediments of the unsaturated portion of the glaciofluvial deposits and the Ringold Formation are essentially dry containing two percent soil moisture by weight below a depth of 10 meters. [8] 


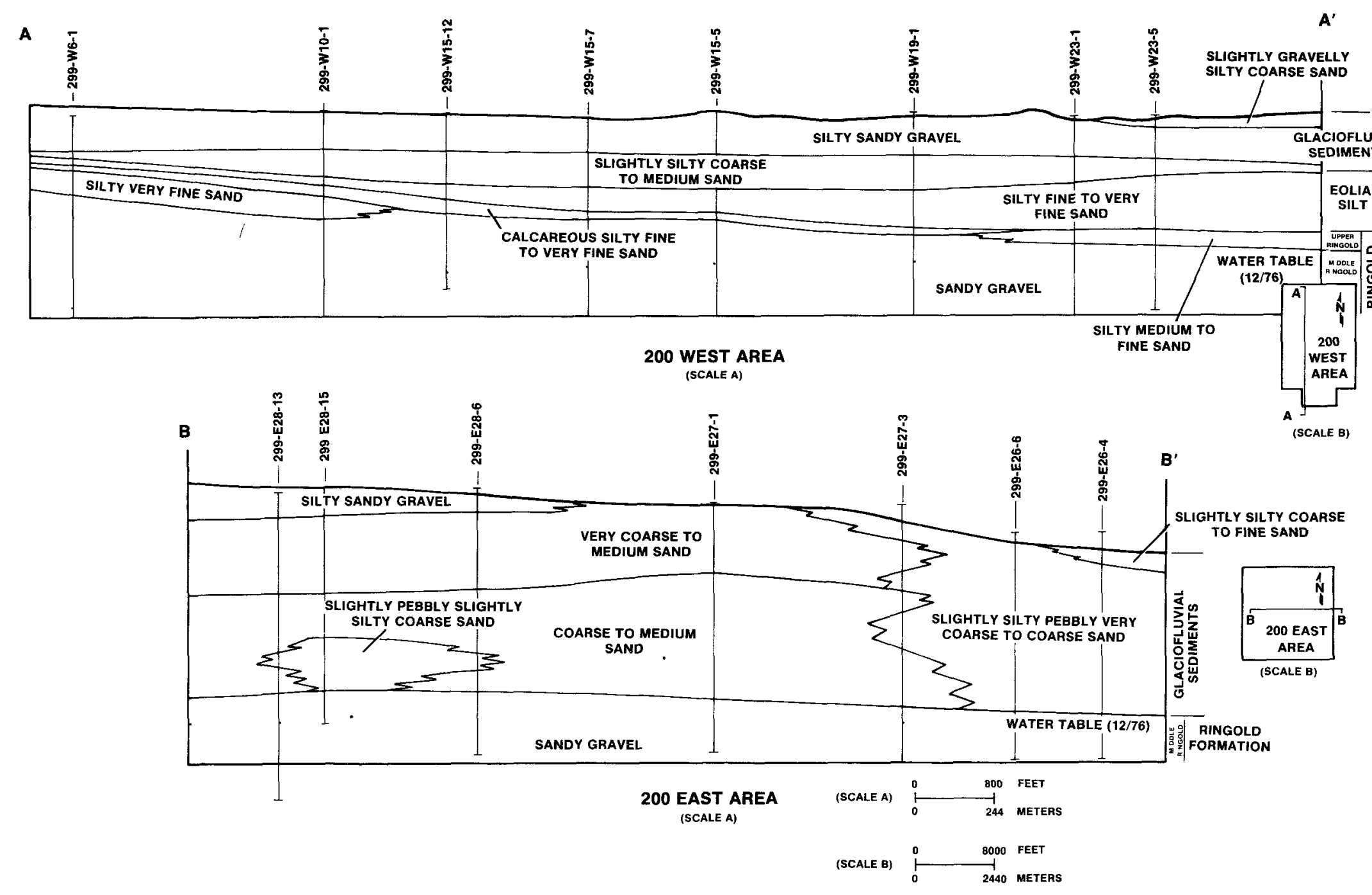

FI GIIRE 3

GEOLOGIC CROSS-SECTIONS OF 200 AREAS

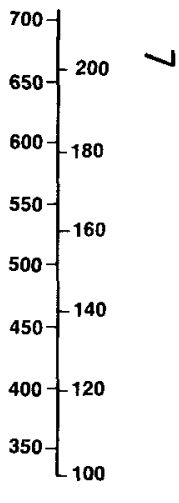


It is into these dry sediments that the liquid wastes containing intermediate and low levels of radionuclides are discharged.

MOVEMENT OF LIQUIDS IN THE VADOSE ZONE

Liquid wastes discharged into the sediments in the vadose zone infiltrate laterally by capillary transport and downward by capillary as well as by gravitational transport. The predominant force, capillary or gravitational, is dependent on the sediment characteristics and residual sediment moisture. Liquid discharged from a point source migrates by capillary transport in homogeneous medium- to fine-grained sediments. The geometry of the wetting front under these conditions is spherical. In homogeneous coarse-grained, saturated sediments, the gravitational forces exceed capillary flow resulting in downward percolation of liquids. The geometry of the wetted sediments under these conditions is a hemi-prolate spheroid.

The structure and stratigraphy of the glaciofluvial and Ringold sediments control the movement of liquid waste through the vadose zone. These sediments are stratified and vary from well-sorted silts and fine sands to well-sorted and poorly-sorted coarse sands and gravels. Stratification tends to increase spreading of liquids along bedding planes and along contacts between sedimentary units. Under partially saturated conditions, liquids migrate by capillary transport across the interface from coarse-grained sediments to finegrained sediments, as liquids move from sediments of lower capillary potential to sediments of higher capillary potential. Liquids then will not percolate downward from finer-grained sediments to coarser-grained sediments under partially saturated conditions. Downward movement from finer-grained sediments to coarser-grained sediments does occur under saturated conditions when gravitational forces exceed capillary forces. 
MOVEMENT OF RADIONUCLIDES IN THE VADOSE ZONE

Analyses of sediment samples obtained by core drilling around waste disposal facilities indicate 99 percent longlived radioactive contaminants are sorbed and filtered out within the glaciofluvial sediments usually within ten meters below the bottom of the crib facilities, high above the water table. $[9,10]$ Different radionuclides discharged to the ground interact with the sediments to different degrees (Figure 4). Tritium moves essentially with the waste liquid with very little, if any sorption, except on clays. Ruthenium is slightly sorbed. Cesium and strontium are tightly sorbed to the sediments beneath crib facilities. Plutonium is sorbed so tightly that essentially all plutonium is held within three meters of the crib bottom. $[7,11]$

EQUIPMENT AND INSTRUMENTATION

Four different scintillation probe systems have been used at Hanford for measuring the intensity of gamma radiation as a function of depth (well logging) over the past twenty-three years. Most of the data were collected by a Hanford-developed logging system that was in use from 1963 to 1974. [12] This logging system was a third-generation system that evolved from earlier-developed instrumentation, and consisted of a detector sonde, armored wire lines, hoisting equipment, and recording and control instruments. [13] The sonde was a 33-centimeter long by 7-centimeter diameter stainless steel can that contained a transistorized preamplifier and a 5.1 x 5.1-centimeter, thallium activated sodium iodide, NaI(Tl), crystal coupled to a photomultiplier tube. The compact system was mounted in the back of a .45 metric ton $4 \times 4$ Carryall. A portable 2.5 kilowatt generator supplied power to operate the equipment. The system had a lower detection limit of about three picocuries (ruthenium-106-rhodium-106) per milliliter in water 


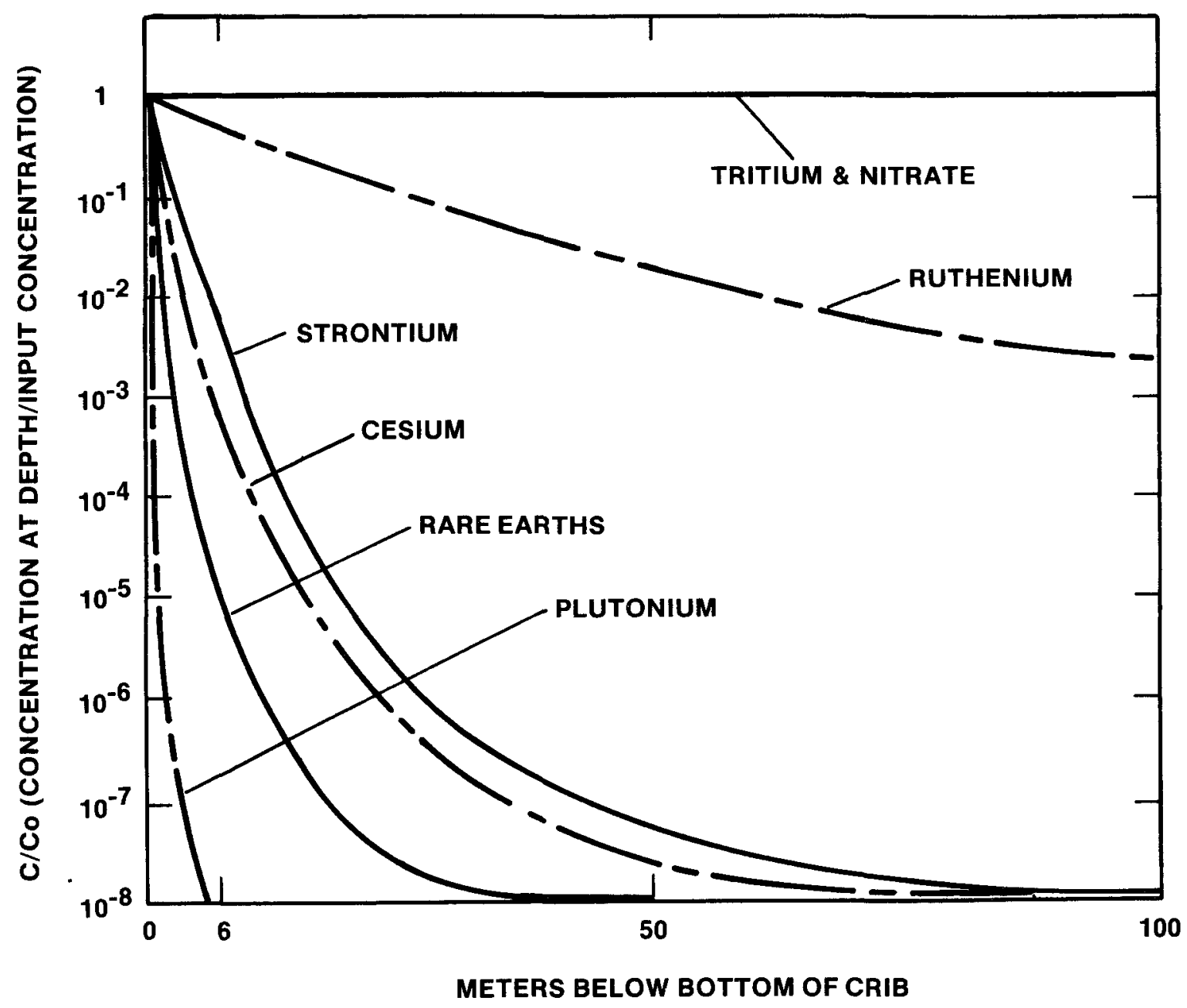

\section{FIGURE 4}

APPROXIMATE SORPTION PATTERNS FOR

TYPICAL 200 AREA DISPOSAL CRIBS 
and about $3 \times 10^{-4}$ millirems (radium-226) per hour in air. Maximum meter count rate in air ( $1 \times 10^{6}$ counts per minute) was reached in a field of about $150 \mathrm{mr} / \mathrm{hr}$. Maximum meter count rate in water occurred at a ${ }^{106} \mathrm{Ru}-{ }^{106} \mathrm{Rh}$ concentration of about 5,000 $\mathrm{pCi} / \mathrm{ml}$.

The output of the detector (sonde) was amplified by a linear pulse amplifier and then fed into a log/linear countrate meter. The rate meter drove a 10-millivolt potentiometric strip chart recorder. The recorder chart drive was coupled to a cable measuring sheave; thus, count rate was recorded against depth of the probe in the well.

Modifications were made in the scintillation probe system in 1966. A miniaturized amplifier-discriminator and a high-voltage power supply were designed and mounted in the probe. This resulted in a lower noise level and a lower background. Overall sensitivity was not materially affected. The rest of the equipment remained unchanged.

This equipment was replaced with a Gearhart-Owen Industries Model 3200 logging system in 1974. [14] The data obtained in 1976 and incorporated in this report were collected by the Model 3200 system. The system is similar to the earlierdeveloped equipment, but incorporates advances made in electronic and mechanical instrumentation over the past 15 years. As with the earlier equipment, the G.O.I. system consists of a detector (sonde), armored wire lines, hoisting equipment, and recording and control instrumentation. Improved detection circuitry of the new logging system increases the lower-1imit sensitivity by approximately a factor of three over the former system.

An analog recorder chart is used with all of the logging systems used at the Hanford Site to record gamma radiation 
intensity (count rate) versus well depth. Required scale changes during logging make direct observation and interpretation of the chart somewhat difficult. Therefore, as was done in this report, the recorder chart data may be digitized, processed by computer, and plotted in logarithmic format (count rate plotted against well depth) for easier examination. The data were also normalized to adjust the background level of the pre-1976 logs to the 1976 values to allow easier, direct comparison of the various logs. The data were normalized by applying appropriate correction factors during computer processing.

\section{PREVIOUS SCINTILLATION PROBE STUDIES}

Scintillation probe studies were conducted in 1964 and 1969 to evaluate the distribution, redistribution and decay of radionuclides discharged to the ground from crib facilities. ${ }^{[3,4]}$ The studies were based on scintillation probe profiles developed from crib monitoring well logging operations between 1954 and 1968. The 1964 study discusses the disposition of radionuclides beneath most of the crib facilities in use up to 1963, while the 1969 study discusses only those crib facilities where changes or lack of changes in the scintillation probe profiles through 1968 were considered significant.

The scintillation probe data from the earlier studies indicated that most of the radioactive contaminants were retained within a short distance beneath the bottom of the crib facilities high above the water table. Downward migration was observed at a number of crib facilities removed from service. The downward migration detected at these crib facilities was attributed to continued drainage of waste liquid in the sediments. Few changes in the disposition of subsurface radioactive contaminants were observed through 1968, except for widespread decreases in subsurface radiation 
intensity. This reflects radioactive decay at sites removed from service and a waste management program that emphasized reduction of disposal of radioactive liquid waste to the environs.

\section{SUMMARY}

Approximately 300 monitoring wells adjacent to over 100 cribs in the 200 Areas were logged with a scintillation probe in 1976. Scintillation probe profiles were developed from these logs taken between 1954 and 1973. The profiles were compiled to measure qualitatively the distribution, redistribution, and decay of radioactive contaminants disposed to the ground beneath crib facilities.

The scintillation probe data indicate that most radioactive contaminants are retained immediately beneath the crib facilities, high above the water table. At 28 crib sites, radioactive contaminants were detected within one meter of the ground surface. Breakthrough of long-lived radionuclides to the groundwater appears to have occurred at 20 crib facilities, based on the evaluation of the data.

No appreciable downward redistribution of radioactive contaminants appears to have occurred after a crib facility has been removed from service. One exception is the 216-B-14 through 216-B-19 crib area in which radioactive contaminants migrated downward as much as 40 meters over a 14-year period (from 1955 to 1968) after disposal to the cribs had been terminated.

The 1976 data from this study indicate that the radioactive contaminants are essentially fixed to the sediments. Few changes on the disposition of subsurface radioactive contaminants are observed in the scintillation probe data, 
except for widespread decreases in subsurface radiation intensity. The decreases reflect radioactive decay at crib facilities removed from service. Beneath active crib facilities, no significant increases in radiation intensity were noted as only 36 curies of activity were discharged to the ground via cribs during 1976. [15]

\section{RESULTS AND DISCUSSION}

Scintillation probe profiles are used to provide a qualitative evaluation of the distribution and redistribution of radioactive waste disposed to the vadose zone via crib facilities. The equipment used recently in logging the crib monitoring wells has been improved over that available in previous logging operations, but the equipment cannot be used to differentiate between various gamma-emitting radionuclides. Some restrictions must be placed on the application of the profile data because monitoring wells are generally located adjacent to crib facilities, rather than directly through the facility. In effect, the profile may not be a complete representation of the status of radioactive contaminants beneath the facilities.

The scintillation probe profiles indicate most of the radioactive contaminants discharged to the ground are retained in the vadose zone. The maximum radiation intensity is generally detected immediately below the crib bottom and the intensity decreases with depth (e.g., Well E24-2 adjacent of the 216-A-10 Crib, Figure A-29; Well W10-3 adjacent to the 216-T-7 Crib and Tile Field, Figure B-75; and W22-12 adjacent to the 216-S-7 Crib, Figure B-24). This is due to (1) the removal of radioactive contaminants by sorption and filtration 
as the waste liquid percolates downward through the partially saturated sediment column; (2) the liquid waste migrating laterally from capillary transport in fine-grained and stratified glaciofluvial and unsaturated Ringold sediments; and (3) the controlled disposal of certain liquid waste to crib facilities, such as liquid waste discharged on a specific retention basis.

Radiation intensity decreased with time throughout the zone of contamination in the vadose zone beneath deactivated crib facilities in all scintillation probe profiles (e.g., Well E25-2, Figure A-3; Well E26-4, Figure A-36; and We11 W22-21, Figure $\mathrm{B}-35)$. These decreases are due to radioactive decay of the waste contaminants discharged to the ground. The decrease in radiation intensity over the years generally increases with depth indicating that the long-lived radionuclides were retained closer to the point of discharge (high within the zone of gamma activity) (e.g., We11 E24-1, Figure A-8; We11 E25-5, Figure A-17; and Wel1 W11-11, Figure B-87).

The scintillation probe data and the position of the monitoring wells relative to the crib show that wastes discharged to the sediments spread laterally in the vadose zone beneath most cribs. The 216-B-7A and -7B Cribs (Appendix A, pages 90 to 96) and the 216-S-1 and -2 Cribs (Appendix $B$, pages 3 to 19) are examples of cribs with monitoring wells that show lateral migration of liquid waste from the crib. The 1956 scintillation probe profile from Well E13-16 (Figure A-101) indicates lateral spreading of liquid waste at least 60 meters from the $216-\mathrm{B}-16$ and -17 cribs.

Geologic features and soil characteristics may appreciably influence the movement of waste in the vadose zone. Beneath the 216-T-6 (Appendix B, pages 72 to 87) Cribs, the migration 
of liquid waste is preferentially controlled by the sediments. The radioactive contaminants detected during scintillation probe logging show migration of waste toward the south, probably along sediment bedding planes. Preferential movement of waste in the sediments is also suspected beneath the 216-T-34 Crib (Appendix B, pages 142 to 145). Radioactivity in the monitoring wells located immediately to the north of the crib is at background level. It is believed that the liquid waste preferentially moved to the south along bedding planes away from the monitoring wells.

The scintillation probe data also indicate that the distribution system for dispensing the waste over the entire length of many of the elongate cribs did not operate as planned. The waste discharged from these cribs entered the ground as a point source near the head end of the crib rather than being evenly distributed along the entire length of the crib (e.g., 216-A-8 Crib, Appendix A, pages 25 to 36; 216-B-62 Crib, Appendix A, pages 235 to 239; and 216-T-35 Crib, Appendix B, pages 146 to 151).

Facilities composed of a crib and connected tile field generally concentrated the radioactive contaminants beneath the crib itself. Apparently the tile fields received only small portions of the total curies of radioactive waste discharged to the facilities (e.g., 216-B-8 Crib and Tile Field, Appendix A, pages 97 to 114; 216-B-9 Crib and Tile Field, Appendix A, pages 115 to 125; and 216-T-7 Crib and Tile Field, Appendix B, pages 88 to 102).

Gamma radioactivity was detected at the ground surface in some scintillation probe profiles (e.g., 216-A-28 Specific Retention Trench, Appendix A, pages 173 to 175 and 216-T-14 Specific Retention Crib, Appendix B, pages 103 to 105). This 
contamination could be due to: (1) contaminated condensates collecting on the inside of well casings at the ground surface; (2) splashing of liquids on the sides of trenches from waste in the trench bottom during back-filling operations; (3) contaminated condensates collecting on the gxound surface from steam vented risers; and/or (4) surface spills of radioactive contaminants during crib operations.

Not all radioactive contaminants are sorbed or filtered out in the vadose zone, and some contaminants have reached the water table (e.g., the higher radiation intensity in the lower portion of the scintillation probe profiles from Well E24-9 [Figure A-44] shows that radioactive contaminants entered the groundwater). An extensive network of monitoring wells has been drilled in the 200 Areas for sampling groundwater. Groundwater from monitoring wells adjacent to active crib facilities is sampled and analyzed routinely. When longlived radionuclides, such as cesium-137, strontium-90, and cobalt-60, detected in the groundwater, reach ten percent of the concentration guide (ERDAM-Appendix 0524, Annex A, Table 2, Column 2), [16] the crib is removed from service and the waste effluent is routed to another crib. The scintillation data indicate possible breakthrough (long-lived radionuclides detected in the groundwater from routine groundwater sampling) at 20 crib facilities in the 200 Areas.

Radioactive contaminants are present at or near the water table based on the scintillation probe profiles from some monitoring wells adjacent to the cribs removed from service. For example, the 216-S-1 and -2 Cribs (Appendix B, pages 3 to 19) were removed from service when relatively high levels of cesium-137 and strontium were found in groundwater samples taken from monitoring wells. [7] Gamma radioactivity is apparent 
throughout the vadose zone from scintillation probe profiles of monitoring wells immediately adjacent to the cribs (see Figures B-3 through B-10).

Radioactive contaminants are redistributed downward in the sediments beneath crib facilities by drainage of liquid effluents through the sediments during crib operations. After discharges to crib facilities are stopped, minor downward redistribution of radioactive contaminants continues for a few years based on the scintillation probe data. The redistribution usually occurs within the zone of contaminated sediments. However, additional penetration of the sediments occurs beneath crib facilities that received relatively large amounts of waste liquids and large quantities of total beta activity (e.g., 216-S-1 and -2 Cribs, Volume III, pages 3 to 19).

Beneath the 216-B-14 through 216-B-19 Crib area, located south of 200 East Area, redistribution on a rather large scale occurred (see Volume II, pages 139 to 158). The cribs at this site received $1.19 \times 10^{8}$ liters of waste 1 iquid and $9.49 \times 10^{5}$ curies of total beta activity. Analysis of the waste revealed that the chemistry of the scavenging process rendered cobalt-60 almost incapable of ion exchange in the sediments (probably due to the formation of complex ions). In places, the radioactive contaminants penetrated an additional 40 meters of the glaciofluvial sediments over a 14-year period. By 1968, the downward penetration had effectively stopped. Disposal of the scavenged waste to cribs, which relied on sorption and filtration as retention mechanisms, was terminated and the waste was discharged to trenches in which limited quantities of waste were discharged to the ground on a specific retention basis. 
The 1967 data from this study indicate that the radioactive contaminants are relatively fixed to the sediments. Few changes in the disposition of subsurface radioactive contaminants are observed in the scintillation probe data, except for widespread decreases in subsurface radiation intensity. This reflects radioactive decay has occurred at crib facilities that have been removed from service. Beneath active crib facilities, no significant increases in radiation intensity were noted as only 36 curies of activity were discharged to the ground via cribs during 1976. [15]

\section{ACKNOWLEDGMENTS}

We wish to express our thanks to Messrs. D. J. Brown, R. E. Isaacson, and W. H. Price and many useful suggestion during the course of this work and to Mr. J. R. Raymond, Battelle-Northwest Laboratories, for providing the computergenerated profiles and for guidance in data interpretation. Mr. V. L. McGhan, Battelle-Northwest Laboratories, retained all historical data and conducted most of the well logging operations. Special thanks go the Ms. T. L. Jones, Ms. E. S. Manship, and Ms. P. S. McInturf for their secretarial and editing assistance.

\section{REFERENCES}

1. R. E. Brown, D. W. Pearce, J. H. Horton, and C. M. Patterson, Experience in the Disposal of Radioactive Wastes to the Ground at Two Production Sites, Proceeding 2nd United Nations International Conference on Peaceful Uses of Atomic Energy, (Geneva, September 1-13, 1968, Vo1. 18, pp. 95-100).

2. G. L. Hanson, J. D. Anderson, B. J. McMurray, G. R. Kiel and N. P. Nisick, Input and Decayed Values of Liquid Radioactive Wastes Discharged to the Ground in the 200 Areas through 1971, ARH-2761, Atlantic Richfield Hanford Company, Richland, Washington, March 1972. 
3. J. R. Raymond and V. L. McGhan, Scintizlation Probe Results - 200 Area Waste Disposal Site Monitoring Wells, HW-84577, General Electric Company, December 17, 1964.

4. D. D. Tillson and V. I. McGhan, Changes in Seintizlation Probe Finding--2964 to 2968, 200 Area Waste Disposal Site Monitoring Wells, BNWL-CC-2255, Battelle Pacific Northwest Laboratories, Richland, Washington, August 31, 1969.

5. H. M. Parker, Ground Disposal of Radioactive Wastes at the Hanford Site, HW-32041, General Electric Company, June 4,1954 .

6. R. E. Brown and H. G. Ruppert, The Underground Disposal of Liquid Wastes at the Hanford Works, Washington, HW17088, General Electric Company, February 1, 1950.

7. U. S. Energy Research and Development Administration, Final Environmental Statement, Waste Management Operations, Hanford Reservation, Richland, Washington, ERDA-1538, Vol. 2, December 1975.

8. R. E. Isaacson, I. E. Brownell, and J. C. Hanson, Soil Moisture Transport in Arid Site Vadose Zones, ARH-2983, Atlantic Richfield Hanford Company, Richland, Washington, October 1974 .

9. D. J. Brown, Migration Characteristics of Radionuclides Through Sediments Underlying the Hanford Reservation, ISO-SA-32, Isochem, Inc., May 29, 1967.

10. W. A. Haney, Final Report on the Effects of Ben Franklin Dam on Hanford to the Richland Operations office, U.S. Atomic Energy Commission, BNWL-412, Battelle Pacific Northwest Laboratories, Richland, Washington, May 1967.

1I. R. C. Routson, A Review of Studies on Soiz-Waste Relationships on the Hanford Reservation from 2944 to 2967, BNWL-1464, Battelle Pacific Northwest Laboratories, Richland, Washington, March 1973.

12. J. R. Raymond, A Gamma Scintizzation Wezz Probe System, HW-81972, General Electric Company, April 23, 1964.

13. W. G. Spear and M. O. Rankin, A Scintizlation WeZZ Logging System, HW-39273, General Electric Company, June 1956 . 
14. Instruction Manual - Pulse Logging Systems, GearhartOwen Industries, Inc., Fort Worth, Texas.

15. J. E. Mirabella, Radioactive Liquid Waste Discharged to Ground in the 200 Areas During 1976, ARH-CD-174-4Q, Atlantic Richfield Hanford Company, Richland, Washington, May 9, 1977.

16. U. S. Energy Research and Development Administration Guides, Manual Chapter Appendix 0524, Annex A, Table 2, Column 2 .

17. C. E. Linderoth and D. W. Pearce, Waste Disposal to the ground, Operating Practices and Experiences at Hanford, HW-SA-36, General Electric Company, July 1959. 
DISTRIBUTION

Number of Copies

Battelle Pacific Northwest Laboratories

K. M. Harmon

V. L. McGhan

D. A. Myers

J. R. Raymond

U. S. Energy Research and Development Administration

5

$\underline{\text { Richland Operations Office }}$

O. J. Elgert

J. A. Fernandez

R. B. Goranson

J. L. Rhoades

M. W. Tiernan

261

Tech Information Center, Oak Ridge, TN

Rockwe11 Hanford Operations
M. K. Additon
R. C. Arnett
R. G. Baca
H. Babad
D. J. Brown
L. E. Bruns
J. Deichman
P. A. Eddy
K. R. Fecht (5)
R. D. Fox
R. J. Gimera
W. M. Harty
T. L. Jones
G. V. Last (5)
M. W. Legatski
C. W. Manry
D. A. Marsh
D. L. Merrick
J. E. Mirabella 


\section{DISTRIBUTION (Continued)}

Rockwe11 Hanford Operations (Continued)

J. V. Panesko

K. R. Price

S. M. Price

W. H. Price (5)

H. P. Shaw

Rockwell Hanford Operations Document Services (3) 